\title{
Dry beans and varying cultural practices at two locations on the coastal plain of Puerto Rico'
}

\author{
James S. Beaver, Obed Román-Hernández, and Luis $E$. Rivera
}

\begin{abstract}
Experiments were conducted over a 3-year period (1983-1985) at Fortuna and Isabela, Puerto Rico, to compare the response of three bean (Phaseolus vulgaris L.) genotypes that differ in growth habit and lodging susceptibility to varying cultural practices. The experimental design was a split plot arrangement of a randomized complete block with three replications. Whole-plot treatments consisted of 0.5 - and $1.0-\mathrm{m}$ row widths. Subplots consisted of a factorial arrangement of three seeding rate treatments (6.6, 13.2, and 19.8 seeds $/ \mathrm{m}$ ) and three dry bean genotypes. All of the bean lines produced the greatest seed yield in the $0.5-\mathrm{m}$ row width with a seeding rate of $19.8 \mathrm{seed} / \mathrm{m}$. The increased yield was the result of an increased number of pods/ha. Indeterminate genotype 2W-33-2 produced the greatest overall seed yield in spite of the fact that it lodged more than the other genotypes. At the Fortuna Substation the seed yield of all genotypes averaged more than $2000 \mathrm{~kg} / \mathrm{ha}$ when grown in $0.5-\mathrm{m}$ row widihs. At the Fortuna Substation there was no significant effect of row spacing or seeding rate on harvest index, whereas at the Isabela Substation harvest index decreased as the seeding rate increased. Plant height and 100 -seed weight were largely unaffected by variation in row spacing and seeding rate. At Fortuna there was more lodging as the seeding rate increased from 6.6 to 19.8 seeds/m.
\end{abstract}

\section{RESUMEN}

Habichuelas y prácticas de cultivo en dos lugares de los llanos costeros de Puerto Rico

De 1983 a 1985 se hicieron experimentos de campo en dos localidades de Puerto Rico para comparar la respuesta de tres genotipos de habichuela (Phaseolus vulgaris L.) a diferentes prácticas de cultivo. Los genotipos de habichuela variaron en hábito de crecimiento $y$ en susceptibilidad a acamarse. Se utilizó un diseño de bloques completos aleatorizados con un arreglo de parcelas divididas con tres repeticiones. Las parcelas enteras consistieron de dos distaneias entre surcos $(0.5$ y $1.0 \mathrm{~m}$.). Las subparcelas consistieron de un arreglo factorial de tres densidades de siembra (6.6, 13.2, y 19.8 semillas $/ m$.) y tres genotipos de habichuela. Con los tres genotipos se obtuvieron los mayores rendimientos en parcelas con $0.5 \mathrm{~m}$. entre surcos y una densidad de siembra de 19.8 semillas $/ m$. Los mayores rendimientos se debieron a un aumento en el número de vainas/ha. EI

Manuscript submitted to Editorial Board 25 February 1988. This research was supported by Puerto Rico Agricultural Experiment Station Hatch Project H-345 entitled "Breeding dry beans for Puerto Rico".

${ }^{z}$ Associate Professor, Researeh Technician, and Assistant Researcher, Dep. Agron. and Soils, Univ. P.R., Mayagüez Campus, Mayagïez, Puerto Rico, 00708. 


\begin{abstract}
genotipo 2W-33-2 produjo los mayores rendimientos, a pesar de que el acamado fue mayor que en los demás genotipos. En Fortuna los rendimientos de los genotipos fueron mayores de 2,000 kg./ha. cuando se sembraron en surcos de $\mathbf{0 . 5} \mathrm{m}$. de ancho. Con relación al índice de cosecha, en Fortuna no hubo diferencias significativas tanto en distancia entre surcos como en densidad de siembra. Por el contrario, en Isabela, el índice de cosecha disminuyó cuando se aumentó la densidad de siembra. La altura de la planta y el peso de 100 semillas no mostraron diferencias significativas al variar la distancia entre surcos y la densidad de siembra. En Fortuna el acamado fue mayor cuando la densidad de siembra se aumentó.
\end{abstract}

\title{
INTRODUCTION
}

Both determinate and indeterminate dry beans (Phaseolus vulgaris L.) are grown in the Caribbean. In Puerto Rico indeterminate whiteseeded beans are used for green shell production (4), whereas traditional red kidney and pink bean varieties have a determinate growth habit (6). Previous research has shown that determinate and indeterminate beans can differ in their response to varying cultural practices $(9,12,16)$. Indeterminate beans are also prone to lodging when grown at high plant populations in productive environments. Severe lodging which occurs early in the growing season has been found to reduce the yield of soybeans (Glycine $\max$ L. Merr.) (7). In recent years indeterminate bean genotypes have been developed, which are more resistant to lodging (1). Beans planted on the coastal plain of Puerto Rico may be grown at narrower row widths and at greater plant densities than are normally reeommended for beans. A more equidistant planting arrangement should result in a more efficient use of light by the leaf eanopy. Greater plant densities, however, may also result in more lodging. The objective of this research was to compare the response of three bean genotypes with different growth habits and lodging susceptibility to different row spacings and seeding rates when grown at two locations on the coastal plain of Puerto Rico.

\section{MATERIALS AND METHODS}

The experiments were conducted over a 3-year period (1983-1985) at the substations located near Juana Díaz and Isabela, Puerto Rico. The Fortuna Substation, located on the southern coastal plain, has a San Antón soil (Cumulic, Haplustolls, fine loamy, mixed, isohyperthermic). It is considered to be a productive environment for beans. The Isabela Substation, located on the northern coastal plain, has a Coto soil (Tropeptic, Haplorthox, clayey, kaolinitic, isohyperthermic).

The experimental design was a split plot arrangement of a randomized complete block with three replications. Whole plots consisted of 0.5 and $1.0 \mathrm{~m}$ row widths. Sub-plots consisted of a factorial arrangement of three seeding rate treatments $(6.6,13.2$, and 19.8 seeds/m of row length) and three dry bean genotypes. Guayamera has a determinate growth habit, and L227-1 and 2 W-33-2 have indeterminate growth habits. The indeter- 
minate genotypes differ in lodging in that L227-1 tends to be more erect than 2W-33-2. Experimental units consisted of three rows, $5 \mathrm{~m}$ long for the $1-\mathrm{m}$ row width treatments and five rows, $5 \mathrm{~m}$ long for the $0.5-\mathrm{m}$ row width treatments.

The 1985 experiment at Isabela was planted in December. The other experiments were planted in January. During the growing season, plots received enough fertilization, irrigation, and weed control to insure vigorous plant growth.

At harvest maturity, plant height measurements and lodging scores were taken. A sample of 10 plants was taken at random from each experimental unit. Number of pods, total plant weight, and seed weight were measured for each sample. Harvest indices were calculated as follows: (sample seed weight/total sample plant weight). Seed yield was estimated by harvesting the center row of the 1-m row width plots and the center three rows of the $0.5-\mathrm{m}$ row width plots. Four-meter row lengths were harvested so that $0.5-\mathrm{m}$ borders could be left at the end of each plot. The weight of 100 seed samples was determined after harvest.

A combined analysis of variance was conducted over years for each location. The effects of years were considered random, whereas the effects of the row spacing, seeding rate and genotype treatments were considered fixed. Treatment means were compared using Fisher's protected L.S.D. (0.05). The response of genotypes to varying seeding rates were also evaluated using orthogonal single degree of freedom comparisons.

\section{RESULTS AND DISCUSSION}

Seed yield averaged $1229 \mathrm{~kg} / \mathrm{ha}$ at Isabela and $1964 \mathrm{~kg} / \mathrm{ha}$ at Fortuna (tables 1 and 2). The greatest yields were produced in the narrower $0.5-\mathrm{m}$ row widths, and the magnitude of the seed yield response to a more narrow row width was similar among genotypes (tables 1 and 2). This finding agrees with results of previous research $(2,3,13)$. The average difference in seed yield between beans grown in 1.0 - and $0.5-\mathrm{m}$ row widths was $496 \mathrm{~kg} / \mathrm{ha}$ at Isabela and $666 \mathrm{~kg} / \mathrm{ha}$ at Fortuna. Genotype $2 \mathrm{~W}-33-2$ produced the greatest seed yield at both locations. In $0.5-\mathrm{m}$ row widths $2 \mathrm{~W}-33-2$ produced an average seed yield of $1,730 \mathrm{~kg} / \mathrm{ha}$ at Isabela and $2552 \mathrm{~kg} / \mathrm{ha}$ at Fortuna. Indeterminate prostrate genotypes have been reported to produce the greatest yield regardless of environment and plant density (16.) Guayamera and L227-1 also produced mean yields greater than $2000 \mathrm{~kg} / \mathrm{ha}$ at Fortuna when grown in $0.5-\mathrm{m}$ row widths (table 1). At Isabela, however, seed yield of the determinate variety Guayamera was much lower than that of L227-1 (table 2). Beaver et al. (5) found that determinate bean genotypes tend to have lower yield potential and have less yield stability than indeterminate bean genotypes. In order to increase yield potential and stability of pink and red kidney 
TABLE 1.-Mean seed yield, pod number, hundred-seed weight, harvest index, plant height and lodging score of three bean genotypes planted at the Fortuna Substation from 1988 to 1985.

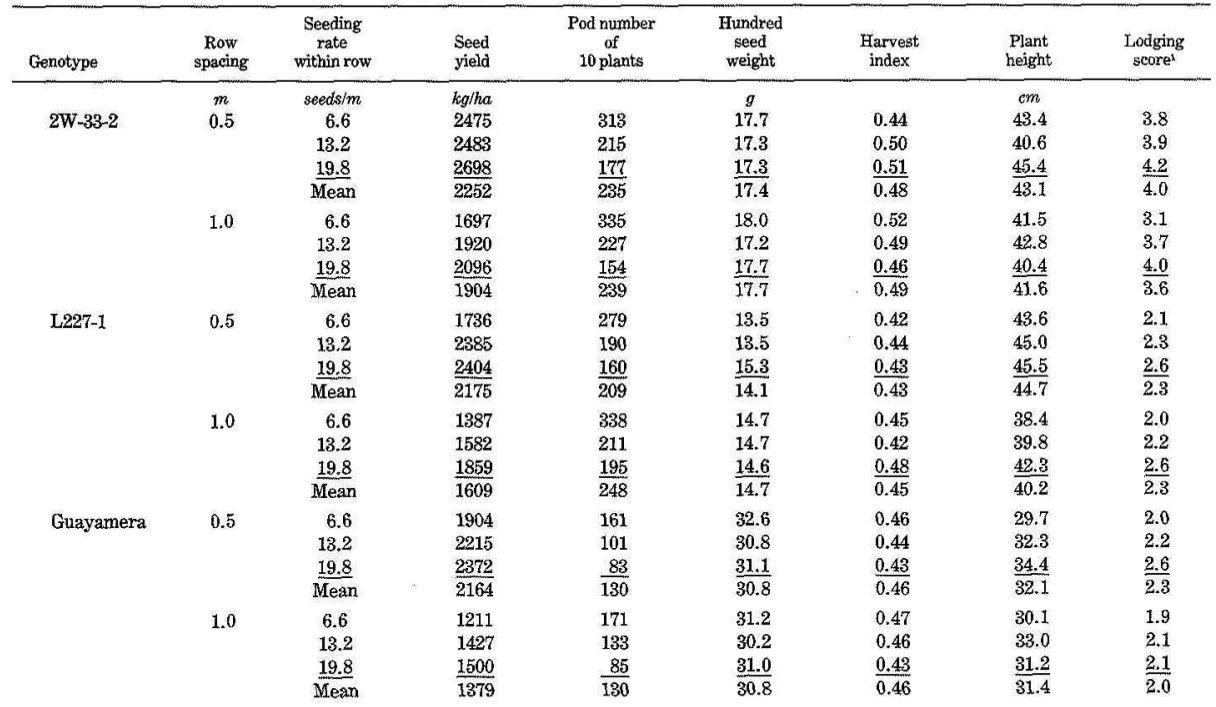


'Rated on a scale from 1 to 5 where $1=$ erect and $5=$ prostrate.

Least Significant Difference $(P=0.05)$ to compare row spacing means of a genotype.

${ }^{3}$ Least Significant Difference $(P=0.05)$ to compare seeding rate means of a genotype at a specific row spacing. 
TABLE 2,-Mean seed yield, pod number, hundred-seed weight, havest index, plant height and lodging score of three

bean genotypes planted at the I sabela Substation from 1983 to 1985 .

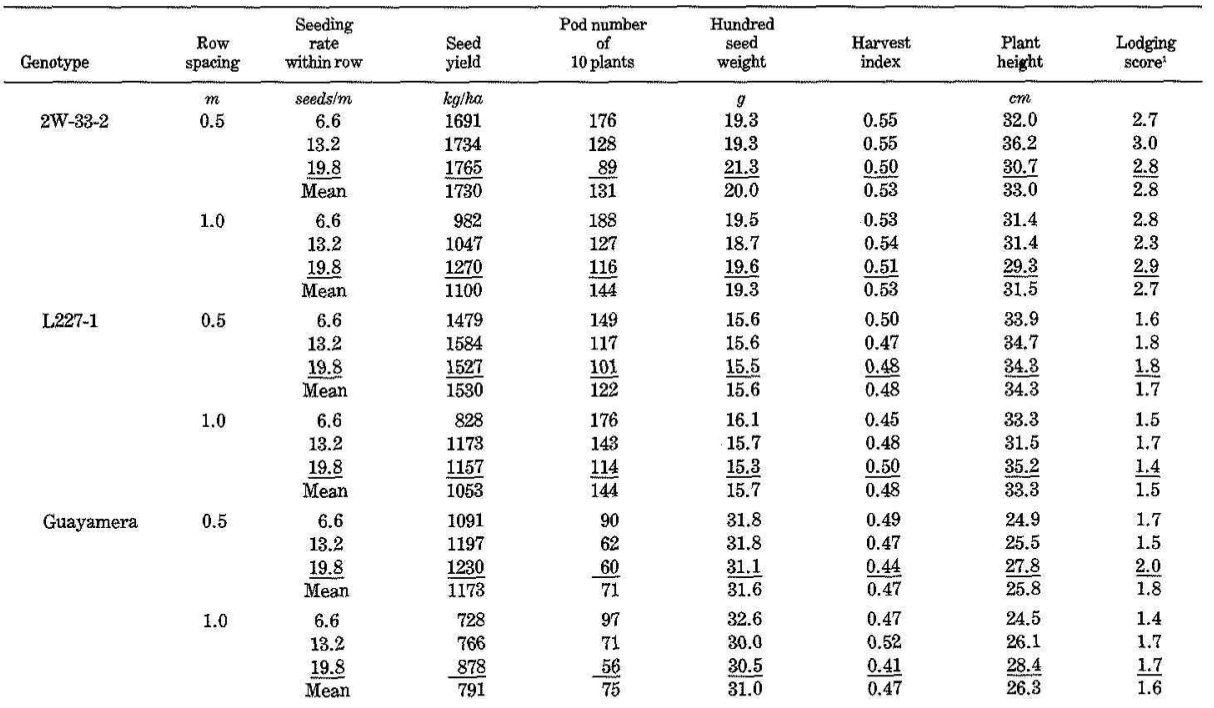


L.S.D. $(0.05)^{2}$

N.S.

N.S.

${ }^{2}$ Rated on a scale from 1 to 5 where $1=$ erect and $5=$ prostrate.

${ }^{2}$ Least Significant Difference $(P=0.05)$ to compare row spacing means of a genotype.

${ }^{3}$ Least Significant Difference $(P=0.05)$ to compare seeding rate means of a genotype at a specific row spacing. 
bean genotypes, erect indeterminate plant types perhaps should be developed as has been reported for pinto beans (11).

Seed yield increased in a linear fashion as the within row seeding rate increased from 6.6 to $19.8 \mathrm{seeds} / \mathrm{m}$ of row (tables 1 and 2 ). The seed yield response to increased within row density was similar among genotypes and for the two row spacings. The magnitude of seed yield response to increase within row density, however, was greater at Fortuna than at Isabela. Results from experiments conducted in productive environments in Mexico (9) indicated that a plant population greater than 288,000 plants/ha would be needed to obtain maximum seed yield. Leaky (15) pointed out that the increased yield resulting from an increased seeding rate would have to be weighed against the additional cost of planting more seed/ha.

Guayamera and 2W-33-2 produced a similar number of pods per plant in 0.5 - and 1.0-m row widths (tables 1 and 2). Genotype L227-1, on the other hand, produced more pods per plant in the $1 \mathrm{~m}$ than the $0.5 \mathrm{~m}$ row widths. Although there was a 3 -fold difference in plant population between the 6.6 and 19.8 seed $/ \mathrm{m}$ seeding rates, the mean number of pods per plant differed by only $53 \%$ at Fortuna and $62 \%$ at Isabela. The result was a greater number of pods per unit area at the greater seeding rate. At Fortuna a quadratic effect of rate was significant for pod number. The difference in pod number between the 6.6 and 13.2 seeds $/ \mathrm{m}$ seeding rates was greater than the difference in pod number between the 13.2 and 19.8 seed/m seeding rates (table 1 ). At Isabela the number of pods per plant decreased in a linear fashion as the within row seeding rate increased from 6.6 to 19.8 seeds $/ \mathrm{m}$ (table 2 ). The rate of decrease, however, varied among years. Several researchers $(9,14,15)$ have reported that number of pods per plant is the seed yield component most affected by variation in plant density.

Guayamera had the greatest 100 -seed weight averaging $30.8 \mathrm{~g}$ at Fortuna and $31.3 \mathrm{~g}$ at Isabela (tables 1 and 2). The indeterminate whiteseeded genotypes $2 \mathrm{~W}-33-2$ and L227-1 averaged 19.7 and $15.7 \mathrm{~g}$, respectively at Isabela, and 17.6 and $14.4 \mathrm{~g}$, respectively at Fortuna. As has been previously reported $(9,14)$, no significant effect of row spacing or seeding rate on 100-seed weight was observed.

Genotype 2W-33-2 produced a greater harvest index than L227-1 and Guayamera (tables 1 and 2). At Fortuna there was no significant effect of row spacing or seeding rate on harvest index (table 1). These results agree in general with Leakey (15), who found harvest index to be fairly constant over a wide range of environmental conditions. There was a concomitant increase in biological yield and seed yield as plant density was increased $(8,10)$. At Isabela, however, the harvest index decreased in a linear fashion as the within row seeding rate increased. Biological 
yield apparently increased at a greater rate than seed yield as the within row seeding rate increased (table 2).

Guayamera, the determinate genotype, was shorter than 2W-33-2 and L227-1, averaging $26 \mathrm{~cm}$ at Isabela and $32 \mathrm{~cm}$ at Fortuna (tables 1 and 2). Plant heights of $2 W-33-2$ and L227-1 averaged 32 and $34 \mathrm{~cm}$, respectively at Isabela, and 42 and $43 \mathrm{~cm}$, respectively at Fortuna. No signifieant effect of row spacing or seeding rate was observed for plant height.

Genotype 2W-33-2 lodged more than L227-1 and Guayamera, with an average score of 2.8 at Isabela and 3.8 at Fortuna (tables 1 and 2). Lodging scores of L227-1 and Guayamera averaged 1.6 and 1.7, respectively at Isabela, and 2.3 and 2.2, respectively at Fortuna. There was no significant effect of row spacing on lodging seore. At Fortuna lodging seores increased in a linear fashion as seeding rate increased. There was less plant growth at Isabela than at Fortuna; consequently, within row seeding rate had no significant effect on lodging scores.

\section{LITERATURE CITED}

1. Adams, M. W., 1982. Plant architecture and yield breeding. Iowa State J. Res. 26 (3): 225-54.

2. Arias, M., 1979. Distancias de siembra en caraota Phaseolus vulgaris L.) en las vegas inundables del río Orinoco. Agron. Trop. 29 (4): 341-47.

3. Badillo-Felieiano, J., M. A. Lugo-López and T. W. Scott, 1978. Effect of planting on yield and agronomic characteristics of red kidney and native white beans in an Oxisol. J. Agric. Univ. P. R. 62 (2): 145-48.

4. _ I. Reyes-Soto and J. S. Beaver, 1985. A comparison of yields of common beans at physiological and harvest maturity. J. Agric. Univ. $P . R .59$ (1); 19-24.

5. Beaver, J. S., C. V. Paniagua, D. P. Coyne and G. F. Freytag, 1985. Yield stability of dry bean genotypes in the Dominican Republic. Crop Sei. 25: 923-26.

6. $\longrightarrow$ J. Badillo-Feliciano and I. Reyes-Soto, 1985. Performance of dry beans when grown on the coastal plains of Puerto Rico. J. Agric. Univ. P. R. 69 (2): 125-34.

7. Cooper, R. L., 1971. Influence of early lodging on yield of soybean [Glycine max (L.) Merr.] Agron. J. 63: 449-50.

8. Díaz, M. F. and E. Aguilar, 1984. Efecto de la densidad de siembra en la distribución de materia seca en la planta de frijol (Phaseolus vulgaris L.). Tumialba 34 (1): 63-76.

9. Immer Agtuilar, M., R. A. Fischer and S. Joshue Kohashi, 1977. Effects of plant density and thinning on high-yielding beans (Phaseolus vulgaris) in Mexico. Eap. Agric. 13: 325-35.

10. Kahn, B. A., R. F. Sansted, P. J. Stofella, and W. L. Hymes, 1981. Effect of between row spacing, cultivation, and genotype on growth and yield of black bean. J. Am. Soc. Hort. Sci. 106 (6): 719-23.

11. Kelly, J. D. and M. W. Adams, 1987. Phenotypic recurrent selection in ideotype breeding of pinto beans. Euphytica $36: 69-80$.

12. Kueneman, E. A., G. Hernández-Bravo, and D. H. Wallace, 1978. Effects of growth habit and competition on yields of dry beans (Phaseolus vulgaris L.) in the tropics. Exp. Agric. 14: 97-104.

13. _ R. F. Sansted, D. H. Wallace, A. Bravo and H. C. Wien, 1979. Effect of plant arrangement and densities on yields of dry beans. Agron. J. 71: 419-24. 
14. $\longrightarrow$ and D. H. Wallace, 1979. Simplified growth analysis of non-climbing dry beans at three spacings in the tropies. Exp. Agric. 15: 273-84.

15. Leakey, C. L. A., 1972. The effeet of plant population and fertility level on yield and its components in two determinate cultivars of Phaseolus vulgaris L. J. Agric. Sei. Camb. 79; 259-67.

16. Nienhius, J. and S. P. Singh, 1985. Effects of location and plant density on yield and architectural traits in dry beans. Crop Sci. 25: 579-84. 